\title{
Çoklu Özellik-Çoklu Yöntem Analizlerinde Kullanılan Farklı Modellere İlişkin Sonuçların İncelenmesi*
}

\section{Examining the Results of Different Models Used in Multitrait- Multimethod Analysis}

\author{
Elif Bengi ÜNSAL ÖZBERK ** $\quad$ Nuri DOĞAN***
}

\begin{abstract}
$\ddot{O} \mathbf{z}$
$\mathrm{Bu}$ çalışmada, çoklu özellik çoklu yöntem matrisleri üzerinde doğrulayıcı faktör analizi yapılırken kullanılacak olan modellerin yöntem kullanma durumları ve özellik ilişkileri açısından farklılıklarına bakılmıştır. Araştırmada, bireylerin problem çözme ve eleştirel düşünme becerileri ele alınarak, yaratıcı düşünme becerilerine ilişkin bir model ortaya konulmuştur. Ortaya konulan model bireylerden anketler sonucu elde edilen puanlar, bireylerin kendilerini değerlendirdikleri puanlar ve akranları tarafindan değerlendirilmesi yöntemleri ile yükseköğretimde öğrenim gören 500 öğrenciden veri toplanarak elde edilmiştir. Farklı yöntemlerin farklı özelliklerle ölçülmesi sonucu oluşturulan çoklu özellik çoklu yöntem matrisi belirlenerek geçerlik ve güvenirlik yorumları yapılmıştır. Ardından model çoklu özellik çoklu yöntem matrislerine uygulanan yöntem ilişkili, bağımsız ilişkili ve eksik yöntem ilişkili modeller ile karşılaştırılarak, kullanılan yöntemlerden hangisinin modeli değerlendirmede uygun olduğu incelenmiştir. Üç farklı yöntem ile elde edilen problem çözme ve eleştirel düşünme becerilerine ait toplam puanlar ile yine üç farklı yöntemin kullanılması ile elde edilen yaratıcılık puanlarının toplamı, bir yapısal modele dönüştürülmüsstür. Problem çözme ve eleştirel düşünme becerileri ile ölçülmeye çalışılan yaratıcılığın ölçme modeli üzerindeki uyumunun kabul edilebilir düzeyde olduğu belirlenmiştir. Çoklu özellik çoklu yöntem matrislerinde Doğrulayıcı faktör analizi model karşılaştırmalarında en iyi uyumu geçerliğe en az katkısı olduğu düşünülen yöntemin modelden atıldığı, geçerliğe ilişkin eksik yöntem ilişkili model vermiş̧ir. En düşük uyumun ise yöntem ilişkisiz modelde olduğu belirlenmiştir. Bu yüzden doğrulatıcı faktör analizinde yöntem ilişkili ve özellikle eksik yöntem ilişkili model çok daha istenir sonuçlar almak adına önerilmektedir.
\end{abstract}

Anahtar Kelimeler: Çoklu özellik-çoklu yöntem matrisi, çoklu özellik-çoklu yöntem matrislerinde doğrulayıcı faktör analizi, yaratıcılık, problem çözme, eleştirel düşünme

\begin{abstract}
In this reseach, method related and trait related specifications are compared in multitrait-multimethod confirmatory factor analysis. Based on persons' problem solving and crticital thinking abilities, a model related to creative thinking abilities was introduced. The model datas collected with self-report, questionnaire and friend report methods in 500 higher education students. Reliability and validity was interpreted in a multitrait-multimethod matrix by measuring the different traits using different methods. Later, correlated method, uncorrelated method and "minus-1" method in multitrait-multimethod confirmatory factor analysis are compared to decide which method works better to evaluate the models. The reliability diagonal values confirmed to be highest values of the matrices while collecting validity evidence in creative thinking ability. The validity coefficients are also different from zero. In validity diagonal, heterotrait-heteromethod triangle and heterotrait-monomethod triangle values is lower than validity diagonal values.Total scores, which was calculated by three diffrent method on problem solving and creative thinking abilities set as a structural model on creative thinking ability. Fit indices of creative thinking model were found acceptable. In multitrait-multimethod matrices, best model to assess creative thinking ability is the "minus-1" model.
\end{abstract}

* Yazarın yüksek lisans tezinin bir kısmını içeren bu çalışma, The 78th Annual Meeting of the Psychometric Society Kongresi'nde sözlü bildiri olarak sunulmuş̧tur.

** Psikolog, Adalet Bakanlığı Ceza İnfaz Kurumları ve Tutukevleri Personeli Ankara Eğitim Merkezi Öğretim Görevlisi, Ankara, Türkiye, elifbengiunsal@gmail.com

*** Doç. Dr., Hacettepe Üniversitesi Eğitim Fakültesi Eğitim Bilimleri Bölümü Eğitimde Ölçme ve Değerlendirme Bilim Dalı, Ankara, Türkiye, ndogan@ gmail.com 
Key Words: Multitrait-multimethod matrices, confirmatory factor analysis, correlated trait-correlated method, correlated trait-correlated uniqueness, creativity, problem solving, critical thinking

\section{GíRiş}

Eğitimde ve psikolojide araştırmacılardan beklenen; merak edilen veya araştırılan yapıya ilişkin örtük değişkenler hakkında kestirimler yapması ve yorumlarda bulunmasıdır. Değişik disiplinlerde ortaya konulan yapılar, eğitimden ve özellikle de psikolojiden farklı olarak daha açık ve nettir. Örneğin fizikteki hız kavramı, yol ve zamanın birer ürünü olarak ortaya çıkabilmektedir ve formülize edilerek hesaplanabilir. Aksine, psikolojideki soyut yapılar fizikte olduğu gibi kolaylıkla ve doğrudan belirlenemez. Bu yüzden davranış bilimleri ile ilgilenen araştırmacılar ölçülmek istenen örtük değişkenlere ait yapıları en doğru şekilde ortaya koymak zorundadırlar.

Psikolojide var olan yapıyı ortaya çıkarmak için testlerden yararlanılır. İster eğitimde olsun isterse de psikolojide testlerden beklenen durum; verilen bir davranış evreni içinde kritik önemi olan psikolojik özellikleri gözlenebilir bir biçimde ortaya koyup, tanımladıktan sonra en az hata ile ölçebiliyor olmasıdır (Lord ve Novick, 1968). Murphy ve Davidshofer'in (1994) de belirttiği gibi testler bireyler hakkında önemli kararlar almak için kullanılmaktadırlar. Bu maksatla, hazırlanan testlerden beklenen, hatalardan olabildiğince arınık ve ölçmek istediği özelliği başka değişkenler karışmadan ölçebilmesidir.

Eğitim ve psikolojide bağımlı değişkenler genellikle davranışlardır ve çoğunlukla doğrudan gözlenemeyen yapıların (construct), bireylerin test maddelerine verdikleri tepkilerle dolaylı olarak ölçülebilmesine dayanır. Dolaylı olarak yapılıyor olsa da testler genellikle psikolojik yapıları ölçmek üzere geliştirilmiştir. Psikolojik yapılar evrendeki devamlılığın soyut özetleridir ve somut, gözlenebilir varlık ve olaylarla ilişkili ve bağlantılıdırlar. (Murphy ve Davidshofer, 1994). Dürüstlük bir psikolojik yapıdır ve doğrudan gözlenemez. Ancak dürüstlüğün doğruyu söyleme davranışı ile ilişkilendirilip anlaşılması ve tanımlanması mümkün olabilmektedir. $\mathrm{Bu}$ gözlenebilen tepkilerin puanlanmasıyla temsilcileri oldukları örtük özelliklere ilişkin ölçümler elde edilmektedir. $\mathrm{Bu}$ ölçüm sonuçlarının betimleme, yorumlama ve karar alma süreçlerinde kullanılabilmeleri için geçerli ve güvenilir olup olmadıklarının kanıtlanması gerekir. Bu bağlamda güvenirlik ve geçerliği tanımlayacak olursak; güvenirlik; ölçme sonuçlarının tesadüfi hatalardan arınıklık derecesidir, geçerlik ise klasik tanımıyla, bir testin, sadece o testle ölçülmek istenen değiş̧eni ölçmesi ve başka değişkenlerle karıştırmamasıdır(akt. Baykul,2000).

Cronbach (1970), geçerlik işleminin, testi geliştiren kişinin, test puanlarından çıkarılacak olan vardamaların tiplerini desteklemek için kanıt toplama süreci olarak tanımlamaktadır. Bu kanıt toplama sürecinde; Messick 1981 yılında yapı geçerliğinin önemini "yapı geçerliği, geçerliğin tümü olmayabilir, ancak şüphesiz geçerliğin kalbidir" cümlesiyle vurgulamaktadır. Bu bakımdan psikolojik yapıların ölçüldüğ̈ bir teste ait geçerlik, yapı geçerliğinin sağlanması ile önemli ölçüde desteklenecektir.

Lord ve Novick (1968) yapı geçerliğini, bir araçla ölçülmek istenen yapının o araçla ortaya konulma derecesi olarak adlandırır. Testin yapı geçerliğini belirlemek isteyen araştırmacı hazırlamış olduğu test ile beklediği davranış arasında bir ilişki kurmalı ve testten yüksek puan alanlarla düşük puan alanların belirlenmek istenen yapıya ne derece sahip olacağını formüle etmelidir (Cohen, 1985). Eğer test, belirlenen yapıyı geçerli bir şekilde ölçüyorsa, yani yüksek puan alanların belirlenen yapıya sahip olma derecesi fazla, düşük puan alanların az ise ölçülmek istenen yapı geçerli bir şekilde ölçülmüştür demektir.

Testin yapı geçerliğine sahip olup olmadığı konusunda verilecek kararlarda birtakım kanıtlar bulmaya çalışmak gerekir. Yapıyı geçerlemede kullanılacak olan bazı teknikler kanıt olarak sunulabilir. Bunların en başında testin homojen olması yani tek bir yapıyı ölçüyor olması bir kanıt olabilir. İkinci olarak da test puanlarının aynı yapıyı ölçtüğü 
varsayılan testler ile olan korelasyonu kanıt olarak kullanılabilir. Üçüncü bir kanıt ise testten elde edilen puanların yaşa veya zamana göre kişiler üzerinde değişip değişmeyeceğinin tahmin edilmesi ve yapının yorumlanmasının bu durum göz önüne alınarak gerçekleştirilmesi gerektiğidir. Yapının geçerliğinin belirlenmesinde kullanılacak bir diğer yol ise aynı bir veya birden çok yapının yine bir veya birden çok yöntem ile ölçülmesi sonucu elde dilecek kanıtlardan olan yakınsama ve ayrımsama kanıtlarıdır. Yapı geçerliği çalışmalarında hem yakınsama geçerliği (convergent) hem de ayırma geçerliği (discriminant) çalışmaları yapılmaktadır ve bu çalışmalar uygulanan yöntemlerin etkisini göstermektedir(Campell ve Fiske,1959).

Psikolojide bir özelliği ölçen farklı sayıda ölçme araçlarının olduğu bilinmektedir. Teoride aynı özelliğin farklı yöntemler ile ölçsek de, ölçme sonuçlarının birbirleri ile ilişkili olması beklenir. Gözlenen herhangi bir değişken için geçerli ölçümler yapmanın iyi bir yolu farklı özellikleri ortaya çıkaracak farklı yöntemler kullanmaktır. Bu amaçla Campbell ve Fiske (1959) çoklu özellik-çoklu yöntem (ÇÖÇY) modelini ortaya koymuştur.

$\mathrm{Bu}$ işlem bir yapının uygunluğunu belirlemekten ziyade daha çok bir yapıyı ölçmek için kullanılan testlerin uygunluğuyla ilgilidir (Campbell ve Fiske, 1959). Yaklaşım birden çok yöntemin ve birden çok özelliğin kullanılmasını içerir. Aynı yöntemlerle farklı yapılar tanımlanır ardından her bir yöntemle her bir yapı için ölçümler elde edilir. Ve birbirleriyle korelasyonları hesaplanır. Bulunan korelasyon katsayıları güvenirlik katsayısı, yakınsama geçerlik katsayısı ve ayırma geçerlik katsayısından biri olarak tanımlanır. Güvenirlik katsayısında aynı yöntem kullanılarak aynı yapının ölçümleri arasındaki korelasyonlara bakılır ve bu korelasyonların yüksek olması beklenir. Yakınsama geçerlik katsayısında farklı yöntemler kullanılarak aynı yapının ölçümleri arasındaki korelasyonlara bakılır ve korelasyonun yüksek olması beklenir. Ayırma geçerlik katsayısında ise aynı ölçme yöntemi kullanılarak farklı yapıların arasındaki korelasyonlar veya farklı yöntemlerle farklı yapılar arasındaki korelasyonlara bakılır, güvenirlik ve yakınsama geçerlik katsayılarından düşük olması beklenir (Erkuş, 2003).

Yakınsama geçerliği bir özelliğimiz ve iki yöntemimiz olduğu durumlarda değerlendirmeye alınır. Örneğin, yakınsama geçerliğini, sınıf performansını (özellik) öğretmen puanlaması (1. yöntem) ve sınıf arkadaşlarının puanlaması (2. yöntem) ile belirlemeye çalışalım. Yakınsama geçerliğini belirleme çalışmasındaki temel düşüncemiz, "Gözlenen ölçümlerin varyansının çoğu özellikten geliyor ise, farklı yöntemler de kullanılsa aynı özellik üzerinde bir kararlılık gözlenmelidir.” olmaktadır (Cohen,1989).

Ayırma geçerliği birden fazla özelliğimiz ve tek bir yöntemimiz olduğu durumlarda değerlendirmeye alınır. Örnek olarak da sınıf performansı (1. özellik) ve sınıf içi dayanışmayı (2. özellik) tek bir yöntem ile takım arkadaşlarının oylamaları ile değerlendirelim. Ayırma geçerliğini belirlemede temel fikir, "Farklı özellikler aynı yöntemlerle ölçülseler bile birbirlerinden ayrımlaşacaklar ve farklılık göstereceklerdir." Özellikler arasında çok az da olsa bir korelasyon beklenebilir ama bu iki özelliğin temelde farklı özellikler olduğu varsayılır. Bazen de faklı özellikler, aynı yöntem ile ölçüldüğünde yüksek derecede ilişkili oldukları durumlar gözlenmiştir. Burada gözlenen varyansın büyük bir çoğunluğunun özellikten değil yöntemden geldiği ayrımına da dikkat edilmelidir (Cohen, 1989).

Klasik Campell ve Fiske yaklaşımı ÇÖÇY matrislerinde yakınsama geçerliği, ayırma geçerliği ve yöntem etkisini belirlemeye yöneliktir. Yakınsama geçerliği, gerçek puanları ya da ortak faktör özelliklerinin varyansını ifade eder ve aynı özelliğin farklı yöntemlerle ölçülmesi sonucunda istatistiksel olarak anlamlı bir ilişki olduğunu ortaya koyar. ÇÖÇY modeli birçok özelliğin ölçülmesinde birden fazla yöntemin her bir özelliğe uygulanmasını gerektirir. Böylece yöntemden ve ölçülmek istenen özellikten 
gelen etkileri de göz önüne almayı amaçlar. ÇÖÇY yaklaşımı genellikle zaman alıcı bir iştir. Bunun hem avantajı hem de dezavantajları olabilir çünkü yaklaşım, özellikler arasındaki ilişkinin varyans bileșenlerini de göz önüne alır. Böylece modelin amacı gözlenen değişkenleri yöntem, özellik ve hata bileşenleri bakımından ayrı ayrı ele almaktadır.

ÇÖÇY modeli için genellikle 3 yaklaşımdan söz edilir.

Doğrulayıcı faktör analizi (DFA)

Kovaryans Bileşenleri Analizi (KBA)

Doğrudan ürün (DÜ) modelleridir (Wathke,1996)

DFA ve KBA ham puanların hesaplanması yöntemden ve özellikten gelen etkinin doğrusal kombinasyonundan kaynaklanan yaklaşım iken DÜ ise karmaşık kombinasyon içermektedir (Dumenci, 2000). ÇÖÇY analizinde DFA bu üç analiz içinde en çok kullanılanıdır. Çünkü DFA, ölçülecek varsayımların yapılarını özellik, yöntem ve hata bileşenleri düzeyinde incelemeye izin verir.

Doğrulayıcı faktör analizi yaklaşımı altında ÇÖÇY matrisi üç ayrı bölümde incelenebilir. Ortak özellik, ortak yöntemin etkisi ve üçüncüsü de herhangi bir özelliğin veya yöntemin etkisine katılmayan dağılımdaki diğer bileşenlerdir.

Özellik İlişskili-Yöntem İlişkili Model (Öİ-Yİ) doğrulayıcı faktör analizi yöntemi olarak Campell ve Fiske'nin (1959) ÇÖÇY modeline en uygunu kabul edilir. Geleneksel ÖİYİ modeli tanımlanan her bir örtük özelliğin farklı yöntemler uygulanarak değerlendirmesini amaçlar. Bu modelde yöntem ve özellik arası ilişkinin sıfır olduğu kabul edilir; dağılım değişkenlerinin birbirinden bağımsız olduğu varsayılır(Eid,2000).

Üç farklı yöntem ( M1 , M 2, M3 ) yardımıyla üç farklı özelliğin (T1, T2, T3 ) ölçüldüğü modelde bulunan $Y j k$ şeklinde ifade edilen değerler, $j$ özelliğinin, $k$ yöntemi ile değerlendirilmesinden elde edilen puanları belirtir (Şekil 1). $E_{j k}$ değerleri de $j$ özelliğinin, $k$ yöntemi ile ölçülmesinden elde edilen hataları belirtir.

Şekil 1: Özellik İlişkili - Yöntem İlişkili Model

Özellik Iilişkili- Yöntem İlişkili Model

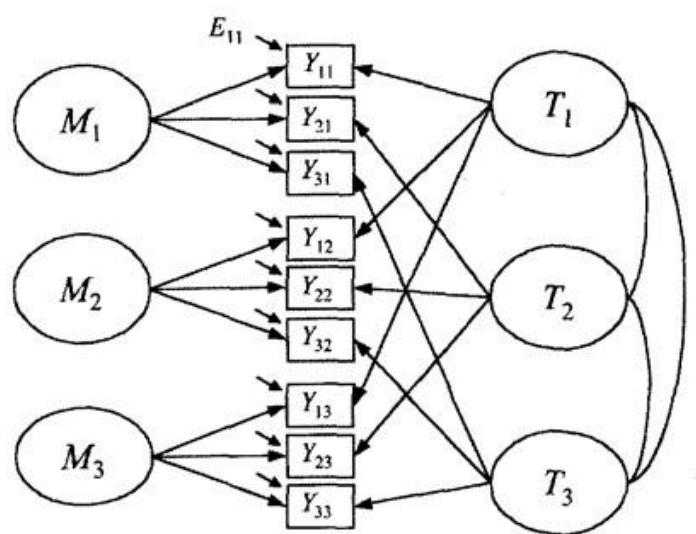

Şekil 1. Özellik İlişkili - Yöntem İlişkili Model

Özellik İlişkili-Bağımsız İlişkili Model, Ölçülen özellikleri yöntemlerden bağımsız olarak belirlemeye çalışan doğrulayıcı faktör analizi modeli Şekil 2’teki gibidir. 


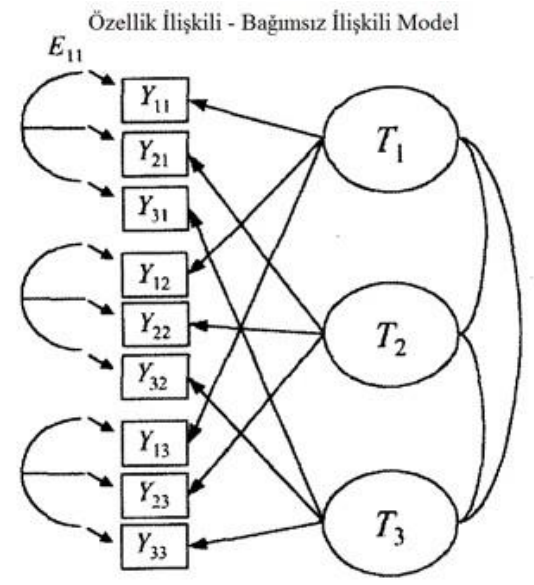

Şekil 2. Özellik İlişkili - Bağımsız İlişkili Model

Bu modelde Öİ-Yİ modelinden farklı olarak yöntem ( $M 1, M 2, M 3$ ) etkisi kullanılmadan, özellikler ( $T 1, T 2, T 3$ ), modelde bulunan $Y j k$ şeklinde ifade edilen değerler ve Ejk hata değerleri yardımı ile belirlenir.

Özellik İlişkili-Eksik Yöntem İlişkili Model, ölçülen özellikleri, yakınsama ve ayırma geçerliğini yansıtması açısından en uygun yöntemin çıkarılması ile oluşturulan eksik yöntem ilişkili doğrulayıcı faktör analizi modeli Şekil 3 'teki gibidir.

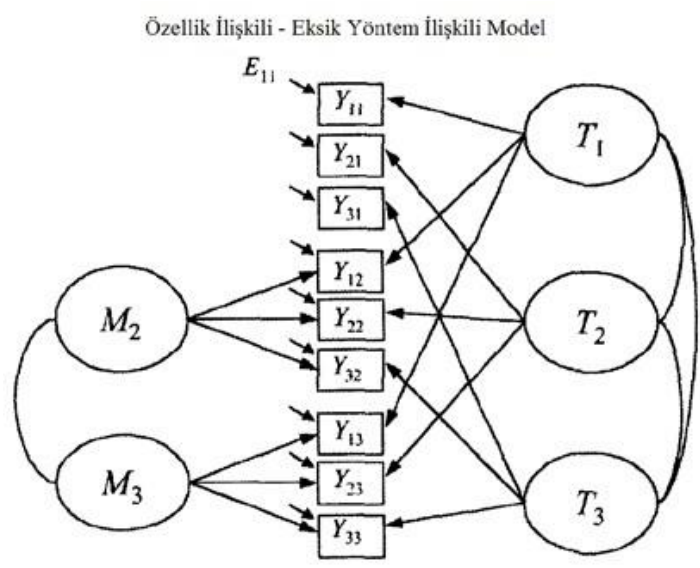

Şekil 3. Özellik İlişkili - Eksik Yöntem İlişkili Model

$\mathrm{Bu}$ modelde Öİ-Yİ modelinden geçerliğe katkısı en az olduğu düşünülen yöntem çıkarılarak (örneğin, $M 1$ ), modelde bulunan $Y j k$ şeklinde ifade edilen değerler ve $E j k$ hata değerleri yardımı ile özellikler ( $T 1, T 2, T 3$ ) belirlenir.

Ülkemizde yapılmış olan doğrulayıcı faktör analizi çalışmaları incelendiğinde, birçok araştırmada özelliklerden ve yöntemden gelen etkinin yakınsama ve ayırma geçerliğine katkısının hemen hemen hiç yapılmadığı, özelliklerle yöntemler arasındaki etkileşimin ortaya konulmadığı ve bu nedenle hataların sadece ölçme hatası olduğu varsayımı hâkimdir. Ancak doğru kestirimlerde bulunmak istenilirse ölçme hatalarının yöntemden ve özellik etkisinden ayrılması ve testin özelliklerine göre uygulanan yöntemlerin en doğru şekilde yorumlanması gerekmektedir. Geçerlik çalışmalarında ÇÖÇY matrislerinin analizinde kurulacak modeller yardımı ile bu fark ortaya koyulmaya çalışılmalıdır. Problem çözme ve eleştirel düşünce becerisinin yaratıcılığı yordadığ 
modeli istatistiksel olarak desteklemek için çoklu özellik çoklu yöntem matrislerini kullanarak kurulan modeli özellik ilişkilerine göre üç farklı model ile test etme yardımıyla geçerliğe ilişkin kanıtlar toplanacaktır. Araştırmada doğrulayıcı faktör analizi çalışmaları yöntem etkisinin kullanıldığı, yöntem etkisinden bağımsız kullanıldığı ve eksik yöntem etkisinin kullanıldığ 1 üç farklı model üzerinden yürütülecektir. Araştırma sonucunda elde edilecek bulgular doğrultusunda doğrulayıcı faktör analizi çalışmalarında kullanılacak üç modelden hangisinin geçerliğe ilişkin kanıtlarını toplamada daha iyi sonuçlar verdiği belirlenmeye çalışılacaktır.

\section{Araştırmanın Amacı}

$\mathrm{Bu}$ çalışmada, çoklu özellik çoklu yöntem matrisleri üzerinde doğrulayıcı faktör analizi yapılırken kullanılacak olan modellerin yöntem kullanma durumları ve özellik ilişkileri açısından farklılıklarına bakılacaktır. Bu kapsamda ayrıca Yaratıcılık Ölçeği'nin diğer ölçeklerle ölçülen yapılarla ilişkisine bakılacak ve geçerlik çalışması yapılacaktır.

\section{YÖNTEM}

Bu araştırma, çoklu özellik çoklu yöntem matrislerinde kullanılan doğrulayıcı faktör analizi modellerini karşılaştırması bakımından kuramsal; kurulan modelin geçerliğine ilişkin kanıtlar toplama bakımından ise betimsel bir araştırmadır.

\section{Çalışma Grubu}

Araştırmanın çalışma grubunu, Kilis 7 Aralık Üniversitesi Eğitim Fakültesinde öğrenim gören 500 yükseköğrenim öğrenci oluşturmaktadır. Doğrulayıcı faktör analizinin uç değerler varsayımı dolayısı ile 20 kişi çalışma grubundan çıkarılmış, araştırma 480 öğrenci üzerinden yürütülmüştür.

Veri Toplama Araçları/Veri Toplama Yöntemleri /Veri Toplama Teknikleri

California Eleştirel Düşünme Eğilimi Ölçeği (The California Critical Thinking Disposition Inventory) (CCTDI)

Ölçek 1990 y1lında Amerikan Felsefe Derneğinin oluşturduğu Delphi projesinin sonucu olarak ortaya çıkmıştır. Ölçeğin 7 alt ölçeği bulunmaktadır. Fakat eleştirel düşünme eğilimini belirlemek amacıyla bu ölçeklerin toplamından oluşan puanlama sistemi kullanılmaktadır (Facione, Facione, ve Giancarlo 1998).

CCTDI'ın benzer eleştirel düşünme ölçeklerinden farklı olarak bir beceriyi ölçmek için değil, kişinin eleştirel düşünme eğilimini, eleştirel düşünme düzeyini değerlendirmek amacıyla kullanılmaktadır. Ölçek toplam 75 maddeden oluşmaktadır. Orijinali İngilizce olan CCTDI Kökdemir tarafından 2003 yılında doktora çalışmasında kullanılmak üzere Türkçe'ye çeviri izni alınmış ve daha sonra orijinal metin, biri araştırmacının kendisi, üçü uzman psikolog, üçü psikolog ve biri de mütercim tercümanlık bölümü öğretim görevlisi olmak üzere toplam sekiz kişi tarafından Türkçe'ye çevrilmiştir.

Kökdemir 2003 yılında 913 öğrenci ile yaptığı çalışma sonrası, toplam 6 alt ölçek ve 51 maddeden oluşan yeni ölçeğin iç tutarlılık katsayısı (alfa) ise 0,88 olarak bulunmuştur. Ölçeğin açıkladığı toplam varyans ise \%36.13'tür. Her bir boyutun iç tutarlık katsayıları (alfa) ise; Analitiklik Alt Ölçeği ve Açık Fikirlilik Alt Ölçeği, 0,75; Meraklılık Alt Ölçeği, 0,78; Kendine Güven Alt Ölçeği, 0,77; Doğruyu Arama Alt Ölçeği, 0,61; Sistematiklik Alt Ölçeği, 0,63'tür (Kökdemir, 2003). 6 aralıklı Likert tipi ölçeğe verilen yanıtlar toplanarak her bir alt ölçek için ham puanlar hesaplanmış ve bu ham puanlar soru sayısına bölündükten sonra 10 ile çarpılarak en düşük 6 ve en yüksek 60 değerini alan bir standart puana çevrilmiştir. Bütün alt ölçekler için olası en düşük ve en yüksek değerler sabittir. 
Facione, Facione, ve Giancarlo (1998: Akt. Kökdemir, 2003) her bir alt ölçek için puanı 40'dan düşük olan kişilerin o boyuttaki eleştirel düşünme eğilimlerinin düşük, puanı 50'den yukarı olanların ise yüksek eleştirel düşünme eğilimine sahip olduklarını söylemektedirler. Dolayısıyla, CCTDI bir bütün olarak değerlendirildiğinde puanı 240'dan $(40$ x 6) az olan kişilerin genel eleştirel düşünme eğilimlerinin düşük, puanı 300 'den $(50$ x 6) fazla olanların ise bu eğilimlerin yüksek olduğu söylenebilir (Kökdemir, 2003).

\section{Yaratıcılık Ölçeği (How Creative Are You?)}

Whetton ve Cameron (2002) tarafından geliștirilen "How Creative Are You" adlı ölçek Aksoy (2004) tarafından "Yaratıcı Düşünme Becerisi Ölçeği” adıyla uyarlanmıştır. Ölçek Aksoy(2004) tarafından Türkçeye çevrilmiş, gerekli istatistiksel analizler yapılarak 40 maddelik son haline getirilmiştir. Ölçek yaratıcı kişiliklerin belirlenmesine yardımcı olmak üzere hazırlanmıştır. Ölçek derecelenme ölçeği olmakla beraber, 40. Soru yaratıcılıkla ilgili 54 tane sıfat verilmiştir. Bu sıfatların ölçekteki puan değeri her bireyin toplam yaratıcılık puanlarının hesaplanmasında, ayrı bir test görünümünde olduğu ve testin uyarlama çalışmalarında da daha önce kullanılmadığı için dikkate alınmamıştır. Ölçekte öğrencilerin yaratıcılık özelliklerini belirlemeye yönelik her bir ifade için "katılıyorum, "kararsızım", "katılmıyorum" seçenekleri verilmiş öğrencilerden kendileri için en uygun ifadeyi seçmeleri istenmiştir. Ölçekte yer alan her maddenin puanlamasi farklıdır, yer alan maddelerin sahip olduğu en düşük puan -2 en yüksek puan 4 'tür.

Ölçekte yer alan 39 maddenin güvenirlik katsayısı Aksoy (2004) tarafından 0.94 bulunmuştur. Faktör analizi sonucunda ölçek tek boyutlu çıkmış açıklanan varyans \%45 olmuştur (Aksoy, 2004).

Ölçekten alınan puanlara göre yaratıcılık düzeyleri;10 puandan az değerler için "Yaratıcılığı Olmayan"; 10-19 puan arası "Ortanın Altında Yaratıcı"; 20-39 puan arası "Orta Düzeyde Yaratıcı"; 40-64 puan aras1 "Ortanın Üzerinde Yaratıcı"; 65-94 aras1 "Oldukça Yaratıcı"; 95-116 puan arası "Olağanüstü Yaratıcı" olarak belirlenmiştir (Aksoy,2004).

Aynı ölçek Akay (2006) tarafından da Türkçeye uyarlanmış ve gerekli istatistiksel analizler yapılmıştır. Yaratıcılık ölçeğindeki her bir madde araştırmacı ve farklı kişiler tarafından Türkçeye çevrilerek, elde edilen çeviriler uzman görüşleri de alınarak daha önceki geçerlilik çalışmasında yapılan Türkçeye uyarlanmış ölçekle karşılaştırılarak uygunluğuna karar verilmiştir. Ölçekte yer alan 39 maddenin güvenirlik katsayısı 0.91 olarak bulunmuştur.

\section{Problem Çözme Envanteri}

Heppner ve Peterson tarafından 1982 yılında kişilerin günlük hayattaki ve kişisel problemlerine nasıl tepkide bulunduğunu, problem çözme becerileri ile ilgili kendini algılayışlarını ölçmek amacıyla geliştirilmiştir. Yapılan çalışmalar sonucu ölçeğin tümü için cronbah alfa iç tutarlılık katsayısı .90'dır. Alt ölçekler için elde edilen katsayılar ise 0.72 ile 0.85 arasında değişmektedir. Ölçeğin madde toplam korelasyon ranj1 0.25 ile 0.71 arasında değişmekte, alt ölçeklerinin test tekrar test güvenirlik katsayıları $\mathrm{r}=0.83$ ile $\mathrm{r}=0.89$ arasında değişmektedir. Yapılan çalışmalar sonucunda "problem çözme yeteneğine güven", "yaklaşma kaçınma", "kişisel kontrol" olmak üzere üç faktörden oluştuğu belirlenmeiştir. Envanterin uyarlanması ve geçerlik güvenirlik çalışmaları ilk olarak Akkoyun ve Öztan tarafından 1988 yılında yapılmıştır. (Akt. Taylan 1990). Ardından birçok araştırmacı tarafından ölçeğin geçerlik ve güvenirlik çalışması yapılmış ve ölçeğin 
kişinin problem çözme becerisini ölçmede geçerli ve güvenilir bir ölçek olduğu belirlenmiş̧ir (Savaşır ve Şahin 1997, Keleş 2000, Güçlü 2003).

Ölçeğin Türkiye Uyarlaması 1993 yılında Nail ve Nesrin Şahin Tarafından yapılmıştır. Toplam 244 üniversite öğrencisi üzerinde yapılan çalışmada ölçeğin Cronbach alfa güvenirlik katsayısı 0.88 olarak bulunmuştur. Tek ve çift sayılı maddeler ayrılarak, yarıya bölme tekniği ile elde edilen güvenirlik katsayısı 0.81 olarak bulunmuştur.

Ölçeğin geçerlik çalışması ölçüt bağıntılı geçerlikle gerçekleştirilmiş, ölçeğin toplam puanı ile Beck Depresyon Envanteri arasındaki korelasyon katsayısı 0.33 ve STAI-T toplam puanı arasındaki korelasyon katsayısı ise 0.45 olarak tespit edilmiştir. PÇE'nin Beck Depresyon Envanteri ve STAI-T' den alınan puanlara göre oluşturulan grupları anlamlı olarak ayırt edebildiği belirtilmiştir. Yapılan diskriminant analizi sonucunda ise ölçeğin disforik ve disforik olmayan grupları \%94 ve \%55 oranlarında; anksiyeteli ve anksiyeteli olmayan grupları ise \%90 ve \%80 oranlarında doğru olarak sınıflandırabildiği ortaya konmuştur (Savaşır ve Şahin, 1997).

Yapılan faktör analiziyle ile ölçeğin; "Aceleci yaklaşım”, "Düşünen Yaklaşım”, "Kaçıngan Yaklaşım”, "Değerlendirici Yaklaşım”, Kendine Güvenli Yaklaşım”, "Planlı Yaklaşım" olmak üzere altı faktörden oluştuğu bulunmuştur (Savaşır ve Şahin, 1997).

Keleş ise 2000 yılında envanterin geçerlik ve güvenirlik çalışmasını yeniden yapmıştır. Yapılan faktör analizi sonucu üç faktörlü bir yapı bulunmuştur. Birinci alt ölçek olan "problem çözme yeteneğine güven" faktöründe 10 madde yer almış, bu maddelerin faktör yük değerleri 0.47 ile 0.82 arasında değişmiştir. Madde toplam korelasyonları ise 0.30 ile 0.73 arasında değerler almıştır. "yaklaşma - kaçınma " alt ölçeğinde 13 madde yer almıştır. Maddelerin faktör yükleri 0.41 ile 0.71 arasındadır. Faktörde yer alan maddelerin madde toplam korelasyonları ise 0.32 ile 0.59 arasında değişmiştir. "kişisel kontrol " alt ölçeğinde bulunan 5 maddenin ise faktör yük değerleri 0.65 ile 0.82 arasında değişmektedir. $\mathrm{Bu}$ beş maddenin madde toplam korelasyonları 0.40 ile 0.65 arasında olduğu belirtilmiştir.

Puan ranj1 32- 192'dir. Ölçekten alınan toplam puanların yüksekliği, kişinin problem çözme becerileri konusunda kendini yetersiz olarak algıladığını belirtir (Savaşır ve Şahin, 1997).

\section{İşlem}

Katılımcılarda çoklu özellik çoklu yöntem matrisleri üzerinde doğrulayıcı faktör analizi yapılırken kullanılacak olan modellerin yöntem kullanma durumları ve özellik ilişkileri açısından farklılıklarının açıklanması ve Yaratıcı Düşünme Becerisi Ölçeği'nin diğer ölçeklerle ölçülen yapılarla ilişkisine ve geçerlik çalışmasının yapılası amaçları doğrultusunda 3 test bataryası oluşturulmuş ve 3 ayrı yöntemle veri toplanmıştır.

Verileri toplamak amacıyla gönüllü olan öğretim üyelerinin dersleri istenmiş ve gönüllü öğretim üyeleriyle beraber 3 yöntemle veri toplanmıştır.

İlk batarya katılımcıların demografik özelliklerini içeren bir bilgi alma formu, California Eleştirel Düşünme Eğilimleri Ölçeği, Yaratıcı Düşünme Becerisi Ölçeği ve Problem Çözme Envanteri'ni içermektedir. Katılımcılardan öncelikle bu test bataryası verilmiş yönergeler okunmuş ve yönergeler doğrultusunda test bataryasını doldurmaları istenmiştir. Doldurulan formlar toplanmamış katılımcıların sıralarının üzerinde ters çevrilmiş olarak bırakılmaları sağlanmıştır. Ardından katılımcıların 1 ile 100 puan arasında kendilerini, eleştirel düşünme becerileri, problem çözme becerileri ve yaratıcı düşünme becerileri açısından puanlayabilecekleri form verilmiştir. Katılımcılardan kendi eleştirel düşünme, yaratıcı düşünme, problem çözme becerilerini 1 ile 100 arasında puanlamaları istenmiştir. $\mathrm{Bu}$ 
formun da sıraya ters olarak kapatılarak bırakılması sağlanmıştır. Son olarak katılımcılara California Eleştirel Düşünme Eğilimleri Ölçeği, Yaratıcı Düşünme Becerisi Ölçeği ve Problem Çözme Envanteri'ni içeren test bataryası verilmiş ve yanında oturan arkadaşlarının bu üç becerisini düşünerek test bataryasını doldurmaları istenmiştir. Bu bataryayı nasıl dolduracaklarına ilişkin bilgi örnekle açıklanarak ayrıntılı bir biçimde yönergeye eklenmiştir. Ayrıca her katılımcı yanındaki arkadaşını değerlendireceğinden veri toplama aşamasının başında her öğrenci sırada çift kişi olmak üzere oturtulmuş, tek sayılı mevcudu olan sınıfta tek oturan katılımcıdan veri toplanmamıştır. Katılımcıların arkadaşlarını değerlendirdikleri test bataryasını da doldurmalarının ardından, doldurulan test bataryalarını da sıralarının üzerinde bırakmaları istenerek sınıf boşaltılmıştır. Boşaltılan sınıfta her bir sıranın üzerinde olan ilk iki forma, yanındaki arkadaşını değerlendirdiği formlar yer değiştirilerek eklenmiştir. Böylece her bir katılımcı için 3 ayrı yöntemle toplanmış, eleştirel düşünme, yaratıcı düşünme ve problem çözme becerisini içeren bir batarya elde edilmiştir.

\section{Verilerin Analizi}

Araştırmada veri analizleri, çoklu özellik-çoklu yöntem matrisinin (MTMM matrix) oluşturulması, DFA sayıltılarının test edilmesi, yaratıcılık becerilerini ölçmek üzere kurulmuş ölçme modelinin uyumunun incelenmesi ve yöntem etkisini kullanma durumlarına göre çoklu özellik-çoklu yöntem matrislerinde farklı üç DFA modelinin karşılaştırılmasından oluşmaktadır.

Araştırmada ilk olarak doğrulayıcı faktör analizi uygulamaları yapılmadan önce test edilmesi gereken varsayımlar incelenmiştir. Her bir ölçekten farklı yöntemlerle elde edilen veriler için aykırı değerler (outlier), kayıp veri (missing data), normallik (multivariate) ve çoklu bağlantılık (multicollinearity) analizleri yapılmıştır (Asil ve Gelbal, 2012).

Varsayımlar test edildikten sonra verilerin çok değişkenli istatistiklere uygun olduğu ancak normallik varsayımını sağlamadığı görülmüştür. Verilerin, normallik varsayımının sağlamadığ1 durumlarda Jöreskog (2002) tarafından önerilen en uygun parametre kestirim yöntemi güçlü maksimum olabilirlik tekniği (Robust Maximum Likelihood-RML) kullanılmıştır.

Yaratıcılık için oluşturulan ölçme modeli LISREL 8.80 programı aracılığı ile doğrulayıcı faktör analizi tekniğinden yararlanılarak geçerlik durumu hakkında kanıt toplanılmaya çalışılmıştır. İlk olarak temel modele dair uyum katsayıları hesaplanmıştır ve modelin veri ile uyumuna karar verebilmek için Ki-Kare, RMSEA, CFI, ECVI, NFI ve GFI uyum indeksleri dikkate alınmıştır. Modelin veri ile uyum gösterdiği görüldükten sonra yöntemlerin farklı şekillerde ele alındığı üç farklı modelin test edilmesine geçilmiştir.

Çoklu özellik çoklu yöntem matrislerinde model tanımlaması yapılması zor olduğu için analiz yapılması da çok güçtür. ÇÖÇY analizleri yapılırken negatif serbestlik derecesi ve uyum problemleri oluşmaktadır. Bu yüzden Bollen (1989) LISREL ile analiz yapılırken gizil değişken varyanslarını 1, özellikler ve yöntemler arasındaki faktör korelasyon değerlerinin de 0 olarak atanması gerektiğini aksi durumda PHI matrisinin pozitif olmayacağını ve analizlerin yapılamayacağını belirtmiştir. Bu yüzden analizlerde Bollen (1989) ve Schumacker ve Lomax (2004) tarafından önerilen komutlar kullanılmıştır.

\section{BULGULAR}

Yaratıcılığa ilişkin geçerlik kanıtlarını toplamada farklı yöntemleri test etmeden önce farklı yöntemlerle elde edilen geçerlik ve güvenirlik değerlerinden oluşturulan çoklu özellik ve çoklu metot matrisi oluşturulmuştur. Bu matriste yorumlara temel olacak 
geçerlik ve güvenirlik köşegenleri ile çoklu özellik - çoklu metot üçgenleri ve çoklu özellik tek metot üçgenleri elde edilmiştir.

Tablo 1: Üç Özelliğin Üç Yöntemle Değerlendirildiği Çoklu Özellik Çoklu Yöntem Matrisi

\begin{tabular}{|c|c|c|c|c|c|c|c|c|c|}
\hline & \multicolumn{3}{|c|}{ Anket } & \multicolumn{3}{|c|}{ Kendini Dĕ̆ } & \multicolumn{3}{|c|}{ Arkadaș Değ } \\
\hline & Pcel & $C d t 1$ & Yol & Pce 2 & $C d t 2$ & Yo2 & Pce3 & $C d t 3$ & Yo3 \\
\hline \multicolumn{10}{|l|}{ Anket } \\
\hline Pcel & 0,95 & & & & & & & & \\
\hline$C d t 1$ & 0,39 & 0,86 & & & & & & & \\
\hline Yol & 0,08 & 0,08 & 0,99 & & & & & & \\
\hline \multicolumn{10}{|l|}{ Kendini Dĕg } \\
\hline Pce2 & 0,25 & 0,22 & 0,10 & 0,86 & & & & & \\
\hline$C d t 2$ & 0,30 & 0,42 & 0,10 & 0,14 & 0,86 & & & & \\
\hline$Y o 2$ & 0,02 & 0,33 & 0,26 & 0,02 & 0,07 & 0,87 & & & \\
\hline \multicolumn{10}{|l|}{ Arkadaş Dĕ } \\
\hline Pce3 & 0,08 & 0,10 & $-0,05$ & 0,01 & 0,17 & $-0,09$ & 0,95 & & \\
\hline$C d t 3$ & 0,28 & 0,54 & 0,11 & 0,22 & 0,43 & 0,02 & 0,16 & 0,87 & \\
\hline Yo3 & 0,10 & 0,05 & 0,21 & $-0,01$ & 0,12 & 0,15 & 0,09 & 0,04 & 0,95 \\
\hline
\end{tabular}

Güvenirlik Köşegeni (Reliabilitiy Diagonals): Her bir ölçümün güvenirlik değerlerini belirtir. Elde edilen korelasyonlar bu örnekte olduğu gibi ölçülen özelliğin, ölçüldüğü yöntem ile ilişkisini vermektedir. Üç farklı özelliğin aynı metotla ölçülmesinden elde edilen güvenirlik katsayılarıdır. Matrisin en yüksek değeri olması beklenir. Elde edilen korelasyonlar bu örnekte olduğu gibi ölçülen özelliğin (problem çözme), ölçüldüğü yöntem ile ilişkisini vermektedir (anket). Tablodan 9 adet güvenirlik katsayısı elde edilmiş ve değerler, 0,86 ile 0,99 arasında değişmektedir. Tablo 1'de problem çözme becerisinin problem çözme becerileri ölçeği ile ölçülmesinden elde edilen güvenirlik değeri 0.95 , kendini değerlendirmesi ile elde edilen güvenirlik değeri 0.86 ve arkadaş değerlendirmesi ile elde edilen güvenirlik değeri de 0.95 'dir. Eleştirel düşünme becerisinin ise California eleştirel düşünme becerileri ölçeği ile ölçülmesinden elde edilen güvenirlik değeri 0.86 , kendini değerlendirme yöntemi ile elde edilen güvenirlik değeri 0.86 ve arkadaş değerlendirmesi ile elde edilen güvenirlik değeri de 0.87 'dir.

Bir diğer değişkenimiz olan yaratıcılığın ise yaratıcılık ölçeği ile ölçülmesinden elde edilen güvenirlik değeri 0.99, kendini değerlendirme yöntemi ile elde edilen güvenirlik değeri 0.87 ve arkadaş değerlendirmesi ile elde edilen güvenirlik değeri de 0.95 'tir.

Geçerlik Köşegeni (Validty Diagonals): Aynı özelliğin farklı yöntemlerle ölçülmesiyle elde edilen korelasyon değerlerini içerir. Bu korelasyon aynı özelliği ölçen iki ölçme için farklı yöntemlerin korelasyonunu verir. Aynı özelliğin farklı yöntemlerle ölçülmesinden gelen değerler Tablo 1'de verilmektedir. Aynı özelliğin farklı yöntemlerle ölçülmesiyle elde edilen geçerlik katsayılarının, tek bir yöntem kullanılarak farklı özelliklerin ölçülmesi ile elde edilen katsayılardan ve farklı özelliklerin farklı yöntemlerle ölçülmesiyle elde edilen katsayılardan daha yüksek olması beklenir. Örnekte eleştirel düşünme becerisi özelliğinin anket ve kendini değerlendirme ile elde edilen korelasyon değeri 0,42 olarak belirlenmiştir. Bu korelasyon aynı özelliği (eleştirel düşünme) ölçen iki ölçme için farklı yöntemlerin (anket ve kendini değerlendirme) korelasyonunu verir. Geçerlik diyagonali değerleri 0,01 ile 0,43 arasında değişmektedir. Tablo4' te problem çözme becericisinin problem çözme envanteriyle ve kendini değerlendirme yöntemi ile ölçülmesinden elde edilenkorelasyon değeri 0.25 , eleştirel 
düşünme becerisinin California eleştirel düşünme becerisi ölçeği ve kendini değerlendirme yöntemi ile ölçülmesinden elde edilen korelasyon değeri 0.42 , yaratıcıllığın yaratıcılık ölçeği ve kendini değerlendirme yöntemi ile ölçülmesinden elde edilen korelasyon değeri 0.26 'dır. Yaratıcılığın, arkadaş değerlendirmesi ve kendini değerlendirme yöntemi ile ölçülmesinden elde edilen korelasyon değeri 0.15 , eleştirel düşünme becerisinin arkadaş değerlendirmesi ve kendini değerlendirme yöntemi ile ölçülmesinden elde edilen korelasyon değeri 0.43 , problem çözmenin arkadaş değerlendirmesi ve kendini değerlendirme yöntemi ile ölçülmesinden elde edilen korelasyon değeri 0.01 'dir. Problem çözme becerisinin problem çözme becerisi envanteri ve arkadaş değerlendirmesi yöntemi ile ölçülmesinden elde edilen korelasyon değeri 0.08 , eleştirel düşünme becerisinin California eleştirel düşünme becerisi ölçeği ve arkadaş değerlendirmesi yöntemi ile ölçülmesinden elde edilen korelasyon değeri 0.54 , yaratıcılığın yaratıcılık ölçeği ve arkadaş değerlendirmesi yöntemi ile ölçülmesinden elde edilen korelasyon değeri ise 0.21 'dir.

Elde edilen bulgulara göre geçerlik köşegeni değerleri; aynı özelliğin farklı yöntemlerle ölçülmesiyle elde edilen korelasyon değerlerini içerir. Geçerlik köşegenindeki tüm katsayıların sıfırdan görünür şekilde farklı olması beklenir. $\mathrm{Bu}$ geçerliğin esas kanıtıdır. Ayrıca aynı özelliğin farklı yöntemlerle ölçülmesiyle elde edilen geçerlik katsayılarının, tek bir yöntem kullanılarak farklı özelliklerin ölçülmesi ile elde edilen katsayılardan ve farklı özelliklerin farklı yöntemlerle ölçülmesiyle elde edilen katsayılardan daha yüksek olması beklenir. Bulgularımız sonucunda aynı özelliğin farklı yöntemlerle ölçülmesi ile elde edilen geçerlik katsayılarının her biri sıfırdan farklı ve genel olarak matristeki çoklu özellik çoklu yöntem üçgenindeki ve çoklu özellik tek yöntem üçgenindeki değerlerin birçoğundan daha yüksek olduğu belirlenmiştir. Ancak bazı geçerlik değerleri olması gerektiğinden farklı olarak çoklu özellik tek yöntem üçgenindeki değerlerden düşük olduğu bulunmuştur. Örneğin (problem çözme arkadaş değerlendirmesi) - (problem çözme kendini değerlendirme) 0.01 korelasyonu, (problem çözme arkadaş değerlendirmesi) - (eleştirel düşünme arkadaş değerlendirmesi) korelasyonundan daha düşüktür. Burada kanıt yöntem faktörü özellikle arkadaş değerlendirmesi yöntemi olabilir.

Çoklu Özellik- Tek Yöntem Üçgeni (Heterotraid- Monomethod Triangles): Tek bir yöntem kullanılarak farklı özelliklerin ölçülmesi ile elde edilen değerlerin ilişkisini verir. Yöntem etkisi bu üçgenden elde edilecek değerler ile yüksek ilişkilidir. Eğer test gerçekten farklı yapıları ölçüyorsa bu değerlerin oldukça düşük çıkması beklenir. Çalışmamızda elde edilen değerler, 0,39 ile 0,02 arasında değişmektedir.

Tablo 1'de problem çözme becerisi ve eleştirel düşünme becerisinin ölçekler ile ölçülmesinden elde edilen korelasyon değeri 0.39 , eleştirel düşünme ve yaratıcılığın ölçekler ile ölçülmesinden elde edilen korelasyon değeri 0.08, yaratıcılık ve problem çözme becerisinin ölçekler ile ölçülmesinden elde edilen korelasyon değeri ise 0.08 'dir. Problem çözme becerisi ve eleştirel düşünme becerisinin kendini değerlendirme yöntemi ile ölçülmesinden elde edilen korelasyon değeri 0.14 , eleştirel düşünme ve yaratıcıllğın kendini değerlendirme yöntemi ile ölçülmesinden elde edilen korelasyon değeri 0.07 , yaratıcılık ve problem çözme becerisinin kendini değerlendirme yöntemi ile ölçülmesinden elde edilen korelasyon değeri ise 0.02 'dir. Problem çözme becerisi ve eleştirel düşünme becerisinin arkadaş değerlendirme yöntemi ile ölçülmesinden elde edilen korelasyon değeri 0.16, eleştirel düşünme ve yaratıcılığın arkadaş değerlendirme yöntemi ile ölçülmesinden elde edilen korelasyon değeri 0.04 , yaratıcılık ve problem çözme becerisinin arkadaş değerlendirme yöntemi ile ölçülmesinden elde edilen korelasyon değeri ise 0.09 'dur. 
Çoklu Özellik- Çoklu Yöntem Üçgeni ( Heterotraid- Heteromethod Triangles): Bu üçgenden elde edilen korelasyonlar farklı özelliklerin farklı yöntemlerle ölçülmesiyle elde edilir. Bu üçgendeki değerlerin matrisin en küçük değerleri olması beklenmektedir. Çalışmamızda elde edilen değerler, 0,30 ile -0,09 arasında değişmektedir.

Yapılan literatür çalışmaları sonucunda yaratıcılığı belirlemede bir model oluşturulmuştur. Üç farklı yöntem ile elde edilen problem çözme ve eleştirel düşünme becerilerine ait toplam puanlar ile yine üç farklı yöntemin kullanılması ile elde edilen yaratıcılık puanlarının toplamı, şekildeki gibi bir yapısal modele dönüştürülmüştür. Analizlerin bu kısmında problem çözme ve eleştirel düşünme becerisi ile ölçülmeye çalışılan yaratıcılığın ölçme modeli üzerindeki uyumu değerlendirilmiştir

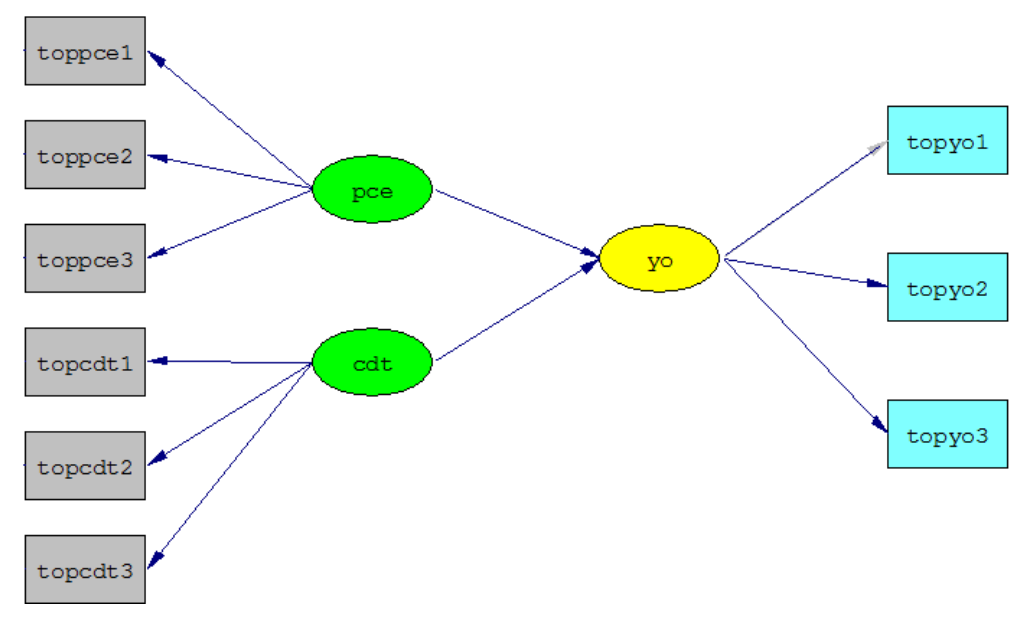

Şekil 4. Yaratıcılığa İlişkin Yapısal Modele Ait Path Diyagramı

Tablo 2: Yapısal Modele İlişkin Uyum İndeksleri

\begin{tabular}{lllllllll}
\hline & $\boldsymbol{x 2}$ & $\boldsymbol{d} \boldsymbol{f}$ & $\boldsymbol{R M S E A}$ & $\boldsymbol{C F I}$ & $\boldsymbol{G F I}$ & $\boldsymbol{A G F I}$ & $\boldsymbol{N F I}$ & $\boldsymbol{N N F I}$ \\
\cline { 2 - 8 } Yapisal Model & 98,16 & 24 & 0,080 & 0,89 & 0,96 & 0,92 & 0,86 & 0,83 \\
\hline
\end{tabular}

Oluşturulan modele ilişkin ki-kare değeri $x^{2}=98,16, \mathrm{sd}=24, \mathrm{p}=0,00$ bulunmuştur. Uyum ve hata indekslerine baktığımızda ise RMSEA $=0.080, \mathrm{CFI}=0.89$ ve GFI $=0.96$ bulunmuş ve modelin bütün değerler bir arada ele alındığında kabul edilebilir olduğu belirlenmiştir.

Oluşturulan yapısal modelinin yöntem etkisi altında doğrulayıcı faktör analizi sonuçlarına ilişkin ise test edilecek modelde yaratıcılık (yo), problem çözme (pce) ve eleştirel düşünme becerileri (cdt); anket (m1), kendini değerlendirme (m2) ve arkadaş değerlendirmesi (m3) yöntemleri ile ilişkili olarak sunulmuştur. Modelde her bir yöntem ile ölçülen özelliklere ait değerler (toppce1, topyo1, vb....) ölçüldükleri yöntem ve özelliğe ilişkili olarak belirlenmiştir. Yaratıcılığa belirlemeye ilişkin yöntemlerin de içinde yer aldığı model aşağıdaki gibi belirlenmiştir. 


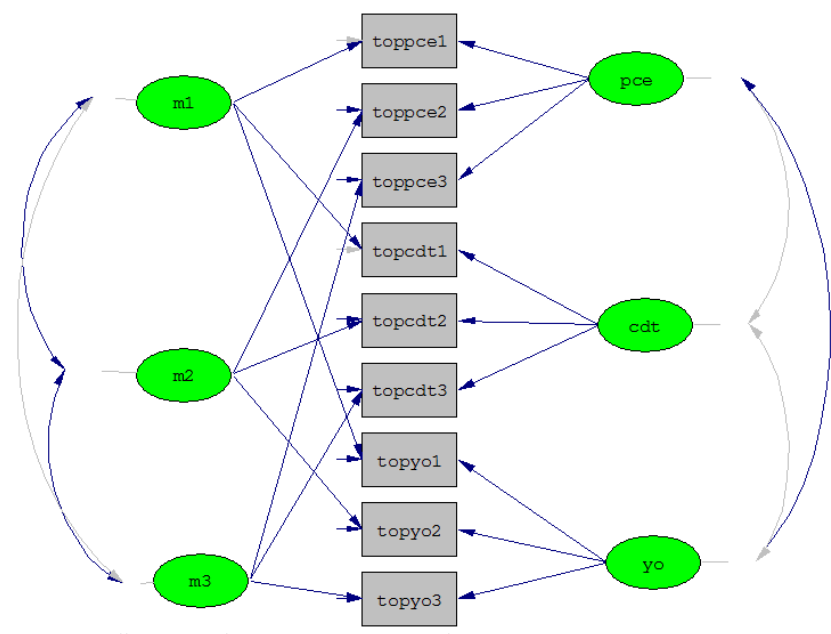

Şekil 5: Özellik İlişkili-Yöntem İlişkili Modele Ait Path Diyagramı

Geçerlik ile ilgili kanıtların toplanmasında anket, kendini değerlendirme ve arkadaşı tarafından değerlendirme yöntemlerini kullanarak kurulan modele ilişkin uyum indisleri aşağıdaki gibidir.

Tablo 3: Model 1'e İlişkin Uyum İndeksleri

\begin{tabular}{lcccccccccc}
\hline $\begin{array}{l}\text { Yöntem İlişkili } \\
\text { Model }\end{array}$ & $\boldsymbol{x 2}$ & $\boldsymbol{d f}$ & $\boldsymbol{R M S E A}$ & $\boldsymbol{C F I}$ & $\boldsymbol{G F I}$ & $\boldsymbol{A G F I}$ & $\boldsymbol{N F I}$ & $\boldsymbol{N N F I}$ & $\boldsymbol{A I C}$ & $\boldsymbol{E C V I}$ \\
\hline
\end{tabular}

Yukarıda belirtilen uyum indekslerine bakılarak üç farklı yöntemin özellikleri belirlemedeki uyumunun kabul edilebilir düzeyde olduğu saptanmıştır.

Oluşturulan yapısal modelinin yöntem etkisi olmadan doğrulayıcı faktör analizi sonuçlarına ilişkin ise test edilecek ikinci modelde yaratıcılık (yo), problem çözme (pce) ve eleştirel düşünme becerileri (cdt); anket (m1), kendini değerlendirme (m2) ve arkadaş değerlendirmesi (m3) yöntemleri olmadan sunulmuştur. Modelde her bir yöntem ile ölçülen özelliklere ait değerler (toppce1, topyo1, vb....) ölçüldükleri yöntem ve özelliğe ilişkili olarak belirlenmesine karşın yöntemler (m1, m2, m3) modele dahil edilmemiştir. Yaratıcılığa ilişkin oluşturulan yapısal modelden yöntem etkisi olmadan elde edilen model aşağıdaki gibi belirlenmiştir.

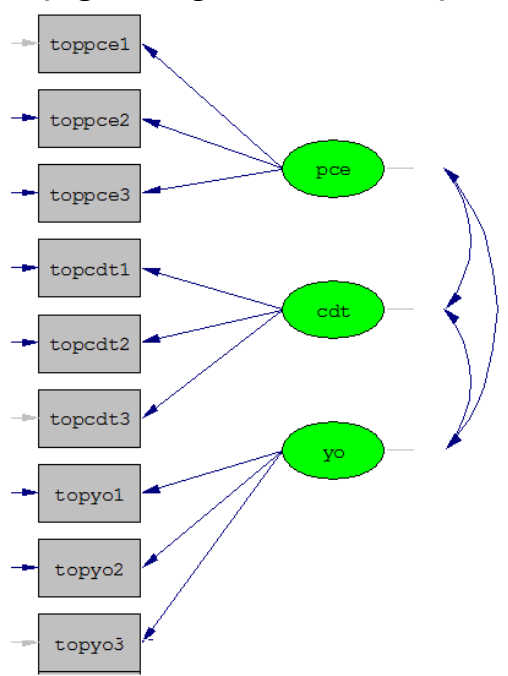

Şekil 6: Özellik İlişkili-Bağımsız İlişkili Modele Ait Path Diyagramı 
Geçerlik ile ilgili kanıtların toplanmasında yöntem etkisi olmaksızın kurulan modele ilişkin uyum indisleri aşağıdaki gibidir.

Tablo 4: Model 2 'ye İlişkin Uyum Indeksleri

\begin{tabular}{lllllllllll}
\hline \multirow{2}{*}{$\begin{array}{l}\text { Yöntem Ilişkisiz } \\
\text { Model }\end{array}$} & $\boldsymbol{x} 2$ & $\boldsymbol{d} \boldsymbol{f}$ & $\boldsymbol{R M S E A}$ & $\boldsymbol{C F I}$ & $\boldsymbol{G F I}$ & $\boldsymbol{A G F I}$ & $\boldsymbol{N F I}$ & $\boldsymbol{N N F I}$ & $\boldsymbol{A I C}$ & $\boldsymbol{E C V I}$ \\
\hline
\end{tabular}

Yukarıda belirtilen uyum indekslerine bakılarak yöntemlerin katkısı olmadan özellikleri belirlemedeki uyumunun kabul edilebilir düzeyde olduğu saptanmıştır (RMSEA=0,079). Yöntemlerin modelden çıkarılması uyum indislerini kısmen olumsuz etkilemiştir. Bunun temel nedeni, gözlenen değişkenlerin varyansı hesaplanırken yöntemden, özellikten ve hata bileşenlerinden gelenleri ayırmamasıdır. $\mathrm{Bu}$ ayrımın olmaması durumunda bütün hatalar ölçme hatası gibi algılanır (Eid ve Diener, 2006).

Oluşturulan yapısal modelinin eksik yöntem etkisi altında doğrulayıcı faktör analizi sonuçlarına ilişkin ise test edilecek son modelde yaratıcılık (yo), problem çözme (pce) ve eleştirel düşünme becerileri (cdt); anket (m1) ve kendini değerlendirme (m2) yöntemleri ile ilişkili olarak sunulmuştur. Modelde her bir yöntem ile ölçülen özelliklere ait değerler (toppce1, topyo1, vb....) ölçüldükleri model ve özelliğe ilişkili olarak belirlenmiştir.

$\mathrm{Bu}$ modelde geçerliğe en az katkısı olduğu düşünülen arkadaş değerlendirmesi (m3) yöntemi modelden atılmış, geçerliğe ilişkin kanıtların toplanması sadece anket (m1) ve kendini değerlendirme (m2) yolu ile ölçülen özellikler modelde yer almıştır. Arkadaş değerlendirmesi yönteminin kullanılmadığı modelin uyum katsayıları tablodaki gibidir: Eksik ilişkili model ile elde edilen uyum indekslerine bakılarak arkadaş değerlendirmesi yönteminin katkısı olmadan özellikleri belirlemedeki iyi bir uyum gösterdiği saptanmıştır (RMSEA=0,041).

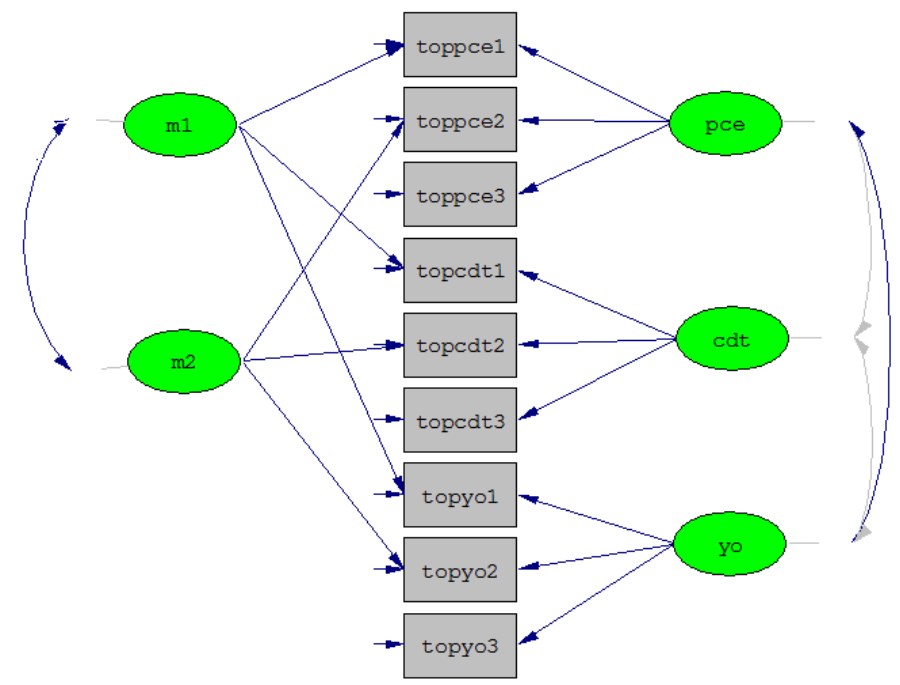

Şekil 7: Özellik İlişkili-Eksik Yöntem İlişkili Modele Ait Path Diyagramı

Tablo 5: Model 3 'e İlişkin Uyum İndeksleri

\begin{tabular}{lllllllllll}
\hline & $\boldsymbol{x 2}$ & $\boldsymbol{d} \boldsymbol{f}$ & $\boldsymbol{R M S E A}$ & $\boldsymbol{C F I}$ & $\boldsymbol{G F I}$ & $\boldsymbol{A G F I}$ & NFI & NNFI & AIC & ECVI \\
\cline { 2 - 9 } $\begin{array}{c}\text { Eksik Yöntem } \\
\text { Ilişkili Model }\end{array}$ & 34,20 & 19 & 0,041 & 0,97 & 0,98 & 0,96 & 0,95 & 0,95 & 86,20 & 0,18 \\
\hline
\end{tabular}


Arkadaş değerlendirmesi yönteminin modelden çıkarılması uyum indislerini son derece olumlu etkilemiştir. Bunun temel nedeni, geçerliği belirlemede kullanılan ayırma geçerliğine daha uygun olduğu, yaratıcılı̆̆ değerlendirilmenin geçerliğe olumlu şekilde katkı etmediğidir.

Geçerlik kanıtlarını toplamada doğrulayıcı faktör analizi yöntemi kullanarak elde edilen üç farklı model içinde geçerliğe en çok katkısı olan, uyum indeksleri en iyi olan eksik yöntem ilişkili modeldir. $\mathrm{Bu}$ araştırmada modeller de karşılaştırıldığı için model karşılaştırmaya ilişkin uyumları gösteren AIC ve ECVI değerleri de belirtilmiştir. AIC ve ECVI değeri en küçük olan modelin daha iyi uyum gösterdiği göz önüne alınırsa (Tanaka, 1993; Jöreskog ve Sörbom, 1993) yine eksik yöntem ilişkili modelin en iyi uyumu gösterdiği söylenir.

$\mathrm{Bu}$ çalışmada arkadaş değerlendirmeleri çıkarıldığında, öğrencilerin yaratıcılıklarını belirlemeye ilişkin geçerliğin daha fazla olduğu gözlenmiştir. Bu bakımdan uyum indisleri en iyi olarak belirlenen eksik yönteme dayalı model geçerlik adına kullanılması en uygun modeldir. Eid ve Diener, (2006) modeller karşılaştırılmak istendiği durumlarda uygulanacak en uygun modelin eksik yöntem modeli olduğunu belirtmişlerdir. Çalışmada elde edilen bulgular, araştırmacıları doğrular niteliktedir.

\section{SONUÇLAR ve TARTIŞMA}

Bu çalışmada, çoklu özellik çoklu yöntem matrisleri üzerinde doğrulayıcı faktör analizi yapılırken kullanılacak olan modellerin yöntem kullanma durumları ve özellik ilişkileri açısından farklılıklarına bakılmıştır. Araştırmada, bireylerin problem çözme ve eleştirel düşünme becerileri ele alınarak, yaratıcı düşünme becerilerine ilişkin bir model ortaya konulmuştur. Ortaya konulan model bireylerden anketler sonucu elde edilen puanlar, bireylerin kendini değerlendirdikleri puanlar ve arkadaşları tarafindan değerlendirilmesi yöntemleri ile elde edilmiştir. Farklı yöntemlerin farklı özelliklerle ölçülmesi sonucu oluşturulan çoklu özellik çoklu yöntem matrisi belirlenerek geçerlik ve güvenirlik yorumları yapılmıştır. Daha sonra model çoklu özellik çoklu yöntem matrislerine uygulanan yöntem ilişkili, bağımsız ilişkili ve eksik yöntem ilişkili modeller ile karşılaştırılarak, kullanılan yöntemlerden hangisinin modeli değerlendirmede uygun olduğu incelenmiştir.

Yaratıcılığa ilişkin geçerlik kanıtlarını toplamada, çoklu özellik ve çoklu metot matrisi oluşturulmuştur. Elde edilen bulgulara göre güvenirlik köşegeni değerleri; her bir ölçümün güvenirlik değerlerini belirtir. Korelasyonlar ölçülen özelliğin, ölçüldüğü yöntem ile ilişkisini vermektedir. Matristeki en büyük değerler olması beklenir. Bulgularımız sonucunda beklendiği üzere bu değerlerin matristeki en büyük değerler olduğu doğrulanmıştır.

Elde edilen bulgulara göre geçerlik köşegeni değerleri; aynı özelliğin farklı yöntemlerle ölçülmesiyle elde edilen korelasyon değerlerini içerir. Bulgularımız sonucunda aynı özelliğin farklı yöntemlerle ölçülmesi ile elde edilen geçerlik katsayılarının her biri sıfırdan farklı ve genel olarak matristeki çoklu özellik çoklu yöntem üçgenindeki ve çoklu özellik tek yöntem üçgenindeki değerlerin birçoğundan daha yükssek olduğu belirlenmiştir.

Üç farklı yöntem ile elde edilen problem çözme ve eleştirel düşünme becerilerine ait toplam puanlar ile yine üç farklı yöntemin kullanılması ile elde edilen yaratıcılık puanlarının toplamı, bir yapısal modele dönüştürülmüştür. Problem çözme ve eleştirel düşünme becerileri ile ölçülmeye çalışılan yaratıcılığın ölçme modeli üzerindeki uyumu değerlendirilmiştir. Modelin elde edilen bulgular 1şığında kabul edilebilir olduğu belirlenmiştir. 
Yaratıcılığı belirlemeye ilişkin yöntemlerin de içinde yer aldığı model oluşturulmuştur. Geçerlik ile ilgili kanıtların toplanmasında anket, kendini değerlendirme ve arkadaşı tarafindan değerlendirme yöntemlerini kullanarak kurulan modele ilişkin uyum indisleri belirlenmiştir. Uyum indislerine bakılarak üç farklı yöntemin özellikleri belirlemedeki uyumu kabul edilebilir düzeydir.

Yaratıcılığa ilişkin oluşturulan yapısal modelin, yöntem etkisi olmadan elde edilen modeli oluşturulmuştur. Geçerlik ile ilgili kanıtların toplanmasında yöntem etkisi olmaksızın kurulan modele ilişkin uyum indisleri belirlenmiştir. Uyum indekslerine bakılarak yöntemlerin katkısı olmadan özellikleri belirlemedeki uyumunun kabul edilebilir düzeyde olduğu saptanmıştır.

Geçerliğe en az katkısı olduğu düşünülen arkadaş değerlendirmesi yöntemi modelden atılmış, geçerliğe ilişkin kanıtların toplanması sadece anket ve kendini değerlendirme yolu ile ölçülen özellikler modelde yer almıştır. Arkadaş değerlendirmesi yönteminin kullanılmadığı modelin uyum katsayıları belirlenmiştir. Eksik ilişkili model ile elde edilen uyum indekslerine bakılarak arkadaş değerlendirmesi yönteminin katkısı olmadan özellikleri belirlemedeki uyumun kabul edilebilir düzeyde olduğu sonucuna ulaşılmıştır.

Yaratıcılığa ilişkin geçerlik kanıtları toplamada yöntemlerin kullanılma durumlarına göre oluşturulan hangi doğrulayıcı faktör analizi modelinin geçerliğe katkısının en fazla olduğunu belirlemek adına modellere ilişkin uyum indekslerini içeren bir tablo hazırlanmıştır. Elde edilen bulgulara göre geçerlik kanıtlarını toplamada doğrulayıcı faktör analizi yöntemi kullanarak belirlenen üç farklı model içinde geçerliğe en çok katkısı olan, uyum indeksleri en iyi olan eksik yöntem ilişkili modeldir.

Araştırmada kullanılan değişkeler ele alındığında problem çözme ve eleştirel düşünce becerisi yaratıcılığı yordamaktadır. Problem çözme becerisi, eleştirel düşünme becerisi ve yaratıcılık birbiriyle ilişkili kavramlardır. Çoklu özellik çoklu yöntem matrisinden elde edilen bulgulara göre yaratıcı̆̆ 1 belirlemede anket yöntemi kendini değerlendirme ve arkadaş değerlendirmesi yönteminden çok daha etkili bir yöntemdir. Kişilerin yaratıcılık düzeylerini belirlemede anket yöntemi daha istenir sonuçlar alma bakımından önerilebilir.

Doğrulayıcı faktör analizi model karşılaştırmalarında ise en iyi uyumu geçerliğe en az katk1sı olduğu düşünülen arkadaş değerlendirmesi (m3) yöntemi modelden atıldığ1, geçerliğe ilişkin kanıtların toplanmasında sadece anket $(\mathrm{m} 1)$ ve kendini değerlendirme $(\mathrm{m} 2)$ yolu ile ölçülen özelliklerin modelde yer aldığ 1 eksik yöntem ilişkili model vermiştir. Ardından en iyi uyumu yöntem ilişkili model vermiş en düşük uyumun ise yöntem ilişkisiz modelde olduğu belirlenmiştir. Gözlenen değişkenlerin varyansı hesaplanırken yöntemden, özellikten ve hata bileşenlerinden gelenleri ayırmadığı için yöntem ilişkisiz model en düşük uyum gösteren modeldir. Bu yüzden doğrulatıcı faktör analizinde yöntem ilişkili ve özellikle eksik yöntem ilişkili model çok daha istenir sonuçlar almak adına önerilmektedir.

Geçerliğin bir kanıt toplama süreci olduğu düşünüldüğünde, bir araç için ne kadar çok kanıt toplanırsa o kadar geçerli olur ancak toplanan kanıtların birlikte değerlendirilmesi gerekir. Bu değerlendirmeyi yapmayı sağlayacak tekniklerden biri olan Çoklu Özellik-Çoklu Yöntem Matrisidir. Bu teknikten yararlanılarak farklı ölçme araçları ile oluşturulan farklı modellerin denenmesi yoluna gidilebilir.

\section{KAYNAKLAR}

Akay, H. (2006). Problem Kurma Yaklaşımıyla Yapılan Matematik Öğretiminin Öğrencilerin Akademik Başarısı, Problem Çözme Becerisi Ve Yaratıcılı̆̆ı Üzerindeki Etkisinin İncelenmesi. Yayınlanmamış Doktora Tezi. Gazi Üniversitesi Eğitim Bilimleri Bölümü 
Aksoy, B. (2004). Coğrafya Öğretiminde Probleme Dayalı Öğrenme Yaklaşımı. Yayınlanmamış Doktora Tezi. Gazi Üniversitesi Eğitim Bilimleri Bölümü

Anastasi, A. (1976). Psychological Testing (4th Edition) Baltimore: MacMillan Publishing Company, Inc.

Asil, M. Gelbal, S. (2012). PISA Öğrenci Anketinin Kültürler Arası Eşdeğerliği. Eğitim Ve Bilim, 37(166), 236-249.

Baykul, Y. (2000). Eğitimde ve Psikolojide Ölçme: Klasik Test Teorisi ve Uygulaması. Ankara: ÖSYM Yayınlar1

Bollen, K.A. (1989). Structural Equations with Latent Variables. New York: John Wiley Sons, Inc.

Campbell D. T., Fiske D W. (1959). Convergent And Discriminant Validation By The Multitrait-Multimethod Matrix. Psychological Bulletin, 56., 81-105

Cronbach, L. J.(1970) Essentials Of Psychological Testing. (3rd Ed) New York: Harper

Cohen, R. J., (1985). Computer-enhanced qualitative research. Journal of Advertising Research, 25(3), 48-52.

Cohen, R., J. (1989). Psychological Testing: An Introduction to Tests \& Measurement. Myfield Pub. New York: Teacher College, Colombia University.

Dumenci, L. (2000). Multitrait-Multimethod Analysis. In H. E. A. Tinsley \& S. D. Brown (Eds.), Handbook of Applied Statistics and Mathematical Modeling (583-611). San Diego, CA: Academic Press

Eid, M. (2000). A Multitrait-Multimethod Model with Minimal Assumptions. Psychometrika, 65., 241-261.

Eid, M., Diener, E. (2006). Handbook of Multimethod Measurement in Psychology. Washington, D.C: American Psychological Association.

Erkuş, A. (2003). Psikometri Üzerine Yazılar. Ankara: Türk Psikologlar Derneği Yayınları.

Facione, P. (1998). Critical Thinking: What It Is and What It Counts. California. California Academic Press.

Güçlü, N. (2003). Lise Müdürlerinin Problem Çözme Becerileri. Milli Eğitim Dergisi, 160, 272-300

Heppner, P. Paul ve Charles J. Krauskopf. (1982). An Information-Processing Approach to Personal Problem Solving. The Counseling Psychologist, 15(3), 371-447

Jöreskog, K. G. (1974). Analyzing Psychological Data By Structural Analysis Of Covariance Matrices. In R. C. Atkinson, D. H. Krantz, R. D. Luce, P. Suppes (Eds.), Contemporary Developments in Mathematical Psychology: Measurement, Psychophysics, and Neural Information Processing Vol:2, 1-56. San Francisco: Freeman.

Jöreskog, K. G., Sörbom, D. (1993). LISREL 8: User's reference guide [Computer Software manual]. Chicago: Scientific Software.

Jöreskog, K.G. (2002). Structural Equation Modeling with Ordinal Variables using LISREL. Available at http://www.ssicentral.com/lisrel/ordinal.htm.

Keleş, O.B. (2000). Ĕgitim Yöneticilerinde Sorun Çözme ve Denetim Odă̆ İliş̧kisi. Yayınlanmamış Doktora Tezi. Ankara Üniversitesi Sosyal Bilimler Enstitüsü. Ankara

Kökdemir, D. (2003). Belirsizlik Durumlarında Karar Verme ve Problem Çözme. Yayınlanmamıs Doktora Tezi. Ankara Üniversitesi. Sosyal Bilimler Enstitüsü. Sosyal Psikoloji Anabilim Dalı. Ankara.

Lord, F. M., Novick, M. R. (1968). Statistical Theories Of Mental Test Scores. Reading MA: Addison-Welsley Publishing Company.

Messick, S. (1981). Evidence And Ethics İn The Evaluation Of Tests. Educational Researcher,10(9): 9-20.

Murphy, K., Davidshofer, C. (1994). Psychological Testing: Principles and Applications (3rd Ed). Englewood Cliffs, NJ: Prentice Hall

Savaşır, I., Şahin N., (1997). Bilişsel Davranış̧̧ı Terapilerde Değerlendirme: Sık Kullanılan Ölçekler. Ankara: Türk Psikologlar Derneği Yayınları.

Schumacker, R.E., Lomax, R.G., (2004). A Beginner's Guide to Structural Equation Modeling (2nd Ed). Mahwah, NJ: Lawrence Erlbaum Associates, Inc.

Tanaka, J.S. (1993). Multifaceted Conceptions Of Fit İn Structural Equation Models. In K.A. Bollen, \& J.S. Long (eds.). Testing Structural Equation Models. Newbury Park, CA: Sage.

Taylan, S. (1990). Heppner'ın Problem Çözme Envanterinin Uyarlama Güvenirlik ve Geçerlik Çalışmaları. Yayınlanmamış Yüksek Lisans Tezi. Ankara Üniversitesi, Ankara

Whetton,D.A., Cameron, K. S. (2002). Answer to Exercises Taken From Developing Management Skills (3rd Ed). Kellog School of Management at Northwestern University Web site: http://www.kellogg.northwestern.edu/faculty/uzzi/ftp/answers.html\#page176 


\section{EXTENDED ABSTRACT}

\section{Introduction}

In education and psychology, behaviors are generally dependent variables. These behaviors (constructs) are indirectly measured with individuals' response to the test items. In this context, construct validity is the appropriateness of inferences made on the basis of observations or measurements, specifically whether a test measures the intended construct construct validty. Construct validity is the degree to which a test measures what it claims, or purports, to be measuring.

Lord ve Novick defined psychological construct in two levels in 1968. First, to define the processes which measure construct; second, to identify the relation with other valid constructs.

Operational definations are inadequate to determine construct validity. Construct validity is significant if it is revealed with other relevant variables. Cronbach (1970), defines validity as a process of accumulating evidance. In this process; Messick emphasised the importance of construct validity and said that "construct validity may not be the whole validty, but definetely heart of validity." In this respect, validity will be proved by ensuring the construct validity.

It is neccesary to find some evidences for making decisions if it has validity constructs or not. Some techniques can be presented that as a proof of construct validation. One of these techniques is evaluation of convergent and discriminant validity with multitrait-multimethod correlations.

Multitrait Multimethod Matrix method for construct validation, as discussed by Campbell and Fiske (1959) the convergent validity coefficients are the correlations between measures of the same trait that are obtained with different measurement methods. Convergent validity is the degree to which concepts that should be related theoretically are interrelated in reality. Discriminant validity is the degree to which concepts that should not be related theoretically are, in fact, not interrelated in reality.

The Multitrait Multimethod Matrix idea provided an operational methodology for assessing construct validity. In the one matrix it was possible to examine both convergent and discriminant validity simultaneously. By its inclusion of methods on an equal footing with traits, Campbell and Fiske stressed the importance of looking for the effects of how we measure in addition to what we measure. And, Multitrait Multimethod Matrix provided a rigorous framework for assessing construct validity.

There are three approaches for Multitrait Multimethod Matrix Models:

Confirmatory Factor Analysis

Covariance Component Analysis

Direct Product

In multitrait-multimethod confirmatory factor analysis can be analyse in three ways: Correlated method, uncorrelated method and "minus-1" method and all of them will be used in this research.

As a result of this research, it is tried to find which method is more efficient at confirmatory factor analysis. In addition to this, it will be analysed the relationship between creativity scale which named "how creative are you?" and the other related scales. Also, creative scale's validation will be studied.

\section{Method}

In this reseach, method related and trait related specifications are compared in multitrait-multimethod confirmatory factor analysis. Based on persons' problem solving 
and crticital thinking abilities, a model related to creative thinking abilities was introduced. The model datas collected with self-report, questionnaire and friend report methods in 500 higher education students. Reliability and validity was interpreted in a multitraitmultimethod matrix by measuring the different traits using different methods. Later, correlated method, uncorrelated method and "minus-1" method in multitrait-multimethod confirmatory factor analysis are compared to decide which method works better to evaluate the models. LISREL 8.80 was used to analyze the models.

\section{Results and Discussion}

The reliability diagonal values confirmed to be highest values of the matrices while collecting validity evidence in creative thinking ability. The validity coefficients are also different from zero. In validity diagonal, heterotrait-heteromethod triangle and heterotrait-monomethod triangle values is lower than validity diagonal values.

Total scores, which was calculated by three diffrent method on problem solving and creative thinking abilities set as a structural model on creative thinking ability. Fit indices of creative thinking model were found acceptable. In multitrait-multimethod matrices, best model to assess creative thinking ability is the "minus-1" model.

If it is considered that validity as a process of accumulating evidance, the more you accumulate evidences the more it is valid. But it is more efficient to discuss all evidances. One of these techniques which ensures validition study is Multitrait Multimethod Matrix. By using this method, validity can be researched by using different scales and different models. 